\section{Tymchenko M.}

State Institution «Zaitsev V.T. Institute of General and Urgent Surgery of National Academy of Medical Sciences of Ukraine», Kharkov

(C) M. Tymchenko

\title{
PREVENTION OF EARLY POSTOPERATIVE COMPLICATIONS OF INTESTINAL SURGERY USING IMMUNOMODULATING THERAPY
}

Summary. The aim of the study is to develop a method of immunocorrection, which improves the results of treatment of patients with developed peritonitis against the background of the small intestine anastomosis leakege by stopping the cascade of SIRS and MOF.

Materials and methods. The work was clinical in nature, was performed in the clinic of the SI «ZIGUS NAMSU» in the period from 2016 to 2019. We examined 58 patients with various diseases of the abdominal organs complicated by peritonitis, in which sections of the small intestine were resected. The Comparison Group included patients who received traditional therapy, patients of the Main Group, the complex of drug therapy included recombinant interleukin-2, galavit and $\alpha$-lipoic acid. The results of surgical treatment were evaluated according to the classification of D. Dindo, N. Demartinesta, P.-A. Clavien (2004). Statistical analysis was removed from the Statistica 6.0 software (StatSoft, Inc. 2001) and SPSS 7.5 on Apple PC.

Results and Discussion. Thus, the results of the use of a comprehensive immunomodulation scheme using IL-2, galavit and $\alpha$-lipoic acid in the complex treatment of patients with widespread peritonitis against the background of intestinal anastomosis failure suggest that the developed scheme has a targeted immunoregulatory effect and prevents the excess production of inflammatory mediators in the early postoperative the period of the disease, helps to eliminate the cytokine imbalance and prevents the development of secondary immune deficiency. A comparative analysis of the incidence of complications revealed that in patients of the Main Group the average number of complications per patient was 0.53 , while in the Comparison Group this indicator was 1.36 .

Conclusions. The use of a combination of IL-2, galavit and $\alpha$-lipoic acid in the complex of treatment of common peritonitis helps to reduce the level of systemic and local postoperative complications, as well as the level of postoperative mortality.

Key words: anastomotic leakage, peritonitis, immunomodulating therapy.

\section{Introduction}

The problem of effective treatment of the developed insolvency of the intestinal anastomosis ultimately comes down to solving the surgical problem of intestinal tube hermeticity and treating peritonitis; the latter remains an urgent task to date, despite the achievements of modern medical science. In $15-25 \%$, the course of urgent surgical diseases is complicated by peritonitis. Mortality in common forms of peritonitis, according to different authors, ranges from 10 to $60 \%$, and in hospital peritonitis it can reach $90 \%[1,2,3]$.

The development of peritonitis is accompanied by the release of pro-inflammatory cytokines, free radicals, a decrease in the efficiency of energyproducing reactions, and severe microcirculatory disorders. Together, these processes contribute to the formation of a systemic inflammatory response syndrome (SIRS), which determines the severity of extra-abdominal complications and multiple organ failure (MOF) [3, 4].

The protective function of SIRS is transformed into a pathological one when a large number of proinflammatory mediators (interleukins: IL-1, IL-6, IL-8) are released into the bloodstream, emission of adhesion molecules from the endothelium and production of growth hormone. The developing acute phase reaction is controlled by endogenous antagonists, such as IL-4, IL-10, IL-13, soluble tumor necrosis factor (TNF) receptors, etc., which are called anti-inflammatory mediators. By maintaining a balance between pro- and anti-inflammatory mediators, prerequisites are created for the destruction of pathogenic microorganisms and the maintenance of homeostasis. However, in case of untimely correction, some cytokines (TNF- $\alpha$, IL-1, IL-6, IL-10) can penetrate into the systemic circulation and accumulate there in quantities sufficient for the 
implementation of damaging effects. In the case of the inability of regulatory systems to maintain homeostasis, the destructive effects of cytokines and other mediators begin to dominate, which leads to impaired permeability and function of the capillary endothelium, triggered disseminated intravascular coagulation syndrome, the formation of distant foci of systemic inflammation, the development of mono- and multiorgan dysfunction $[1,3,4,5,6]$.

At the stage of SIRS syndrome, from the standpoint of the interaction of pro- and anti-inflammatory mediators, it is possible to conditionally separate two periods. The first, initial - period of hyperinflammation, characterized by the release of ultra-high concentrations of pro-inflammatory cytokines, nitric oxide (NO), which contributes to the development of shock and the formation of MOF syndrome in the early stages. However, already during this period, compensatory secretion of anti-inflammatory cytokines occurs, their secretion rate, concentration in blood and tissues gradually increase with a parallel decrease in the content of inflammatory mediators. A compensatory anti-inflammatory response develops, combined with a decrease in the functional activity of immunocompetent cells - the period of «immune paralysis». Thus, a «vicious circle» arises - increasing endogenous intoxication (EI) causes a number of changes leading to inhibition of the immune system, which, in turn, contributes to the progression of the systemic inflammatory response, the increase in intoxication, the development of MOF. In some patients, due to genetic determination or reactivity altered by environmental factors, the formation of a stable anti-inflammatory reaction immediately occurs $[3,6,7,8]$.

A key pro-inflammatory mediator is TNF. Its important role is associated with the biological effects of this mediator: increased procoagulant properties of the endothelium, activation of neutrophil adhesion, induction of other pro-inflammatory cytokines, stimulation of catabolism, fever and synthesis of «acute phase» proteins. The generalization of damaging effects is mediated by the widespread prevalence of TNF receptors and the ability of other cytokines to liberalize it. From a practical point of view, it is extremely important to note that the reaction rate of the septic cascade with widespread peritonitis increases sharply under conditions of hypoxia due to the expression of cytokine receptors on the cell surface $[5,8]$.

In the genesis of acute vascular insufficiency underlying septic shock syndrome, the leading role is played by NO, the concentration of which increases tenfold as a result of stimulation of macrophages TNF, IL-1, IFN, and later secretion is also carried out by smooth muscle cells of blood vessels and the monocytes themselves are activated under the influence of NO. In addition, the participation of the nitroxidergic system in the development of immunopathological reactions and the systemic inflammatory response syndrome is known. Therefore, it is advisable to study the effect of the NO system, cytokines on the apoptosis of immunocompetent cells and the development of treatment methods that can to some extent influence the systemic inflammatory response, and therefore, prevent the development of MOF [5, 9].

With widespread peritonitis as a result of dysfunction of the liver, kidneys, intestines, new factors of harmful effects appear. Their role is played by intermediate and final products of normal metabolism in high concentrations (lactate, urea, creatinine, bilirubin); components and effectors of regulatory systems accumulated in pathological concentrations (kallikrein-kinin, coagulation, fibrinolytic, lipid peroxidation, neurotransmitters); products of «perverted» metabolism (aldehydes, ketones, higher alcohols), substances of intestinal origin such as indole, skatol, putrescine $[5,7,10]$.

Traditionally, intensive therapy of peritonitis includes full surgical debridement of the infection site, adequate antimicrobial and detoxification therapy. At the same time, maintaining the patient's life, preventing and eliminating organ dysfunction is impossible without targeted immunocorrection $[1,11]$.

The inclusion in the intensive care complex of common peritonitis of drugs that can regulate the production of inflammatory mediators will help to control a systemic inflammatory response, as well as prevent the depletion of immunocompetent cells and the development of secondary immunodeficiency. Given the complexity of developing immune disorders, it is advisable to use drugs with complex immunomodulatory effects, aimed at weakening the immunosuppressive effect of a group of endogenous anti-inflammatory mediators and a dosed increase in the production of cytokines with immunostimulatory activity, as well as drugs that are straightforward to block macrophage systems $[5,7$, $11,12]$. Allow you to recognize the sensitivity of the receptors to hormones, to unlock the receptor device, and to be sure to attend to them. All this will increase the body's sensitivity to drug therapy.

\section{Aim}

Study is to develop a method of immunocorrection, which improves the results of treatment of patients with developed peritonitis against the background of the small intestine anastomosis leakege by stopping the cascade of SIRS and MOF.

\section{Materials and methods}

The work was clinical in nature, was performed in the clinic of the SI «ZIGUS NAMSU» in the period from 2016 to 2019 . We examined 58 patients with various diseases of the abdominal organs complicated by peritonitis, in which sections 
of the small intestine were resected. The reasons for the development of peritonitis were: strangulated hernia, adhesive obstruction of the intestine, inversion of the small intestine, segmental mesenteric thrombosis, perforation of the small intestine (acute ulcers, diverticula). The comparison group included 28 patients, in the study group there were 30 patients. The groups were comparable in terms of gender, age, causes of peritonitis and the severity of the disease. Among the subjects were persons of both sexes aged 17 to 68 years, among them there were 38 men (65.5\%) and 20 women $(34.5 \%)$.

All patients were operated on urgently. After eliminating the source of peritonitis, all patients underwent abdominal sanitation, intubation of the small intestine (nasointestinal or transcecal), abdominal drainage with four or more silicone drains.

The comparison group included patients who received traditional therapy, usually in the intensive care unit. The treatment included antibiotic therapy, intensive infusion therapy, correction of hemodynamic, water-electrolyte disturbances, detoxification, symptomatic treatment. If necessary, inotropic stimulation and hardware support for respiratory activity were performed.

The volume and composition of infusion therapy depended on the initial state of central and peripheral hemodynamics, the degree of disturbance of the water-electrolyte balance, and the compensatory capabilities of the myocardium. On average, with an average degree of severity, the infusion volume was $50 \mathrm{ml} / \mathrm{kg}$; in severe condition, patients reached $70 \mathrm{ml} / \mathrm{kg}$. Antibacterial therapy was carried out on the principle of de-escalation.

After the stabilization of vital functions and basic metabolic parameters, patients were transferred to the general surgical department.

Comprehensive examination of patients included the study of anamnestic and clinical data, physical examination of the patient, analysis of general clinical and biochemical parameters, the results of instrumental examination methods.

To assess the effectiveness of treatment, we studied changes in the indicators of the immune status, cytokine concentration, nitric oxide level and the activity of the processes of apoptosis of immunocompetent cells (ICC), as well as the level of cryoglobulinemia.

Isolation of cryoglobulin from blood serum was performed according to the method of A.E. Kalovidoris with modifications. The study of the general population of T-lymphocytes in blood serum was carried out using monoclonal antibodies by immunofluorescence method on an enzyme-linked immunosorbent analyzer STAT-FAX303, USA. The content of immunoglobulins (Ig) in blood serum was studied using enzyme-linked immunosorbent assay systems manufactured by NPL «GranumUkraine». The study of circulating immune com- plexes (CIC) was determined in blood serum by the method of Hashkov et al. (1977). TNF- $\alpha$ in serum was detected using enzyme-linked immunosorbent assay systems manufactured by Protein Loop OJSC (Russia), and Diaclone (France). The state of the NO synthase system was evaluated according to the methodological recommendations of the Ministry of Health of Ukraine «Diagnosis of endothelial function - assessment of a vasoactive pool of nitric oxide». Nonspecific immunological resistance of the organism was studied on the basis of the study of the phagocytic activity of neutrophils.

In patients of the Main Group, the complex of drug therapy included recombinant interleukin-2 (in the form of an intravenous infusion of 500,000 IU once a day for 2 days with a break of 2-3 days, the general course of at least 2,000,000 IU), galavit (100 mg intramuscularly 2 times per day for at least 5 days) and $\alpha$-lipoic acid (in the form of intravenous infusion of $600 \mathrm{mg}$ with a solution of sodium chloride $0.9 \% 250 \mathrm{ml} 1$ time per day for at least 5 days).

Interleukin-2 (IL-2) is produced by a subpopulation of T-lymphocytes (T-helpers I) in response to antigenic stimulation. The synthesized IL-2 acts on T-lymphocytes, enhancing their proliferation and subsequent synthesis of IL-2. The biological effects of IL-2 are mediated by its binding to specific receptors present on various cellular targets. IL-2 directionally affects the growth, differentiation and activation of $\mathrm{T}$ and $\mathrm{B}$ lymphocytes, monocytes, macrophages, oligodendroglial cells, Langerhans cells. The development of the cytolytic activity of natural killers and cytotoxic T-lymphocytes depends on its presence. IL-2 causes the formation of lymphokine-activated killers and activates tumorin-filtering cells. The expansion of the therapeutic effect of the effect of arable cells leads to the elimination of a variety of pathogenic microorganisms, infected and malignant cells, provides immune defense against tumor cells, as well as pathogens of viral, bacterial and fungal infections.

Galavit is a 5-amino-1,2,3,4-tetrahydrophthalazine-1,4-dione sodium salt. It primarily regulates the synthesis of cytokines by macrophages (IL-1, TNF, etc.) and lymphocytes (IL-2), as well as the proliferative activity of natural killer cells (NK cells) by reversibly inhibiting the synthesis of hyperactive macrophages of pro-inflammatory cytokines for 6-8 hours or stimulating them with initial failure. At the same time, galavit is able to restore the phagocytic function of macrophages and neutrophils and, therefore, anti-infection protection.

The administration of $\alpha$-lipoic acid eliminates the blockade of the macrophage system (the release of the phagocytic mononuclear system is carried out) and thereby optimizes the elimination functions of cryoglobulins. There is a restoration of the sensitivity of receptors to hormones, the release of the receptor apparatus, is associated with drugs, 
which explains the increase in the body's sensitivity to drug therapy.

The results of surgical treatment were evaluated according to the classification of D. Dindo, N. Demartinesta P.-A. Clavien (2004).

Statistical analysis was removed from the Statistica 6.0 software (StatSoft, Inc. 2001) and SPSS 7.5 on Apple PC.

\section{Results}

Changes in the immune system with an immunoregulatory index (IRI) score and phagocytic index $(\mathrm{PhI})$ in patients of the Comparison Group who received traditional therapy are presented in table 1 and 2.

The data obtained show that under the stress of biological adaptation systems, in response to the action of infectious agents, cytokine synthesis is activated, which causes a temporary or permanent disruption in the regulation of the production of certain cytokines, in particular IL-2, IL-6, and tumor necrosis factor (Table 1, 2).

It should be noted that the duration of immunocorrection in patients of the main group in each case was determined individually (depending on the severity of the general condition of the patients and the data of laboratory studies in dynamics). An analysis of the results allowed us to formulate the general principles of immunocorrection in patients with purulent infection of the abdominal cavity in the preoperative and postoperative periods.

The dynamics of changes in the immune status with an immunoregulatory index (IRI) score and phagocytic index $(\mathrm{PhI})$ in patients of the Main Group are presented in table 3 and 4 .

\section{Discussion}

The study of the immune status in patients of the Main Group, as well as in patients of the Comparison Group, in the first day after surgery revealed inhibition of a non-specific immunity. However, already on the 7 th day of observation, there was a significant increase in the content of the CD2+ fraction $(66.5 \pm 3.2 \%)$ compared with the initial values. Throughout the entire period of the study, the $\mathrm{PhI}$ increased, reaching normal values on day 14, while in patients of the Comparative Group during these periods the indicator remained low (Table 1). On the 14th day of treatment in patients of the Main Group, the values of the relative and absolute contents of blood lymphocytes, fractions of CD2+, CD4+ and immunoregulatory index were restored.

The concentration of Ig A, Ig G, Ig M immunoglobulins was normal and significantly differ-

Dynamics of changes in immunogram indices in patients of the Comparison Group $(\mathrm{M} \pm \mathrm{m})$

\begin{tabular}{|l|c|c|c|c|}
\hline \multirow{2}{*}{ Blood count } & \multirow{2}{*}{ Norm } & \multicolumn{3}{c|}{ Day of observation } \\
\cline { 3 - 4 } & & $\mathbf{1}$ Day & $\mathbf{7}$ Day & 14 Day \\
\hline Lymphocytes, \% & $28-39$ & $28,1 \pm 2,1$ & $24,2 \pm 2,1^{*, * *}$ & $13,3 \pm 2,51^{* *}$ \\
\hline Lymphocytes, count (cells/mkI) & $1600-2400$ & $1264,8 \pm 8,62^{* *}$ & $1115,3 \pm 4,91^{*}$ & $987 \pm 8,21$ \\
\hline T-lymphocytes, \% & $67-76$ & $48,2 \pm 4,1^{*}$ & $47,6 \pm 3,1^{*, * *}$ & $49,8 \pm 4,3^{*, * *}$ \\
\hline T-helpers, \% & $38-46$ & $28,5 \pm 2,3^{* *}$ & $24,6 \pm 1,1^{*, * *}$ & $16,4 \pm 1,3^{*, * *}$ \\
\hline T- suppressors, \% & $28-40$ & $21,9 \pm 3,4^{* *}$ & $22,3 \pm 0,4^{*, * *}$ & $26,7 \pm 0,5^{*}$ \\
\hline IRI (Th/Ts) & $1,2-2,0$ & $1,29 \pm 0,3$ & $1,1 \pm 0,3$ & $0,6 \pm 0,1^{*, * *}$ \\
\hline Ig A, g/l & $1,4-4,2$ & $5,2 \pm 0,5$ & $3,4 \pm 0,8$ & $0,8 \pm 0,2^{*, * *}$ \\
\hline Ig G, g/l & $8,0-1,66$ & $6,7 \pm 1,2^{* *}$ & $5,3 \pm 1,1^{* *}$ & $4,4 \pm 1,6^{*, * *}$ \\
\hline Ig M, g/l & $0,5-1,3$ & $1,5 \pm 0,3$ & $1,3 \pm 0,5$ & $1,1 \pm 0,4$ \\
\hline CIC, units. & $0-100$ & $70,5 \pm 3,4$ & $81,8 \pm 4,3^{*}$ & $101,6 \pm 3,3^{*}$ \\
\hline Phl, \% & $40-80$ & $23,6 \pm 2,7^{* *}$ & $17,1 \pm 1,41$ & $11,2 \pm 1,2^{*, * *}$ \\
\hline
\end{tabular}

Notes: * significance of differences compared with the source data $(\mathrm{p}<0.05)$; ** significance of differences compared with normal values $(\mathrm{p}<0.05)$

Table 2

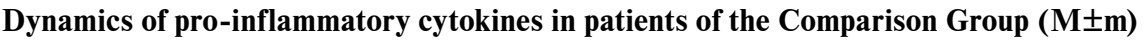

\begin{tabular}{|c|c|c|c|c|c|c|c|c|}
\hline \multirow{2}{*}{ Interleukins, pg/mI I } & \multirow{2}{*}{ Norm } & \multicolumn{7}{|c|}{ Day of observation } \\
\cline { 3 - 9 } & & 1 Day & 3 Day & 5 Day & 7 Day & 10 Day & 14 Day & 25 Day \\
\hline IL-2 & $130,5 \pm 21,1$ & $85,2 \pm 2,4^{* *}$ & $99,7 \pm 4,2^{* *}$ & $106,7 \pm 5,7^{*, * *}$ & $89,4 \pm 3,4^{*, * *}$ & $68,5 \pm 4,2^{* *}$ & $62,6 \pm 4,3^{* *}$ & $56,3 \pm 1,4^{*, * *}$ \\
\hline IL-6 & $303,1 \pm 10,4$ & $756,2 \pm 7,8^{* *}$ & $606,6 \pm 5,2^{*, * *}$ & $571,3 \pm 6,2^{*, * *}$ & $561,3 \pm 4,6^{*, * *}$ & $553,8 \pm 5,7^{*, *}$ & $526,3 \pm 8,1^{*, * *}$ & $496,5 \pm 9,4^{*, * *}$ \\
\hline TNF- $\alpha$ & $4,27 \pm 1,23$ & $19,6 \pm 2,72$ & $16,5 \pm 2,82$ & $9,6 \pm 3,11$ & $15,2 \pm 2,12$ & $16,8 \pm 3,42$ & $17,4 \pm 2,62$ & $17,9 \pm 2,82$ \\
\hline
\end{tabular}

Notes: * significance of differences compared with the source data $(\mathrm{p}<0.05)$; ** significance of differences compared with normal values $(\mathrm{p}<0.05)$ 
Table 3

Dynamics of changes in immunogram indices in patients of the Main Group $(\mathrm{M} \pm \mathbf{m})$

\begin{tabular}{|c|c|c|c|c|}
\hline \multirow{2}{*}{ Blood count } & \multirow{2}{*}{ Norm } & \multicolumn{3}{|c|}{ Day of observation } \\
\hline & & 1 Day & 7 Day & 14 Day \\
\hline Lymphocytes, \% & $28-39$ & $27,5 \pm 1,3$ & $28,2 \pm 1,6$ & $34,3 \pm 2,4^{*, * * *}$ \\
\hline Lymphocytes, count (cells/mkl) & $1600-2400$ & $1342,2 \pm 6,52$ & $1528,4 \pm 8,8^{*, * *}$ & $2346 \pm 11,8^{*, * * *}$ \\
\hline T-lymphocytes, \% & $67-76$ & $50,5 \pm 2,3$ & $66,5 \pm 3,2$ * & $75,3 \pm 3,5^{*, * * *}$ \\
\hline T-helpers, \% & $38-46$ & $28,3 \pm 3,6$ ** & $28,3 \pm 3,6$ *** & $48,1 \pm 3,3^{*, * * *}$ \\
\hline T-suppressors, $\%$ & $28-40$ & $23,1 \pm 2,7^{* *}$ & $28,3 \pm 2,1^{*}$ & $34,2 \pm 2,8^{*, * * *}$ \\
\hline IRI (Th/Ts) & $1,2-2,0$ & $1,22 \pm 0,4$ * & $1,36 \pm 0,6$ & $1,4 \pm 0,3$ * \\
\hline $\lg \mathrm{A}, \mathrm{g} / \mathrm{l}$ & $1,4-4,2$ & $4,2 \pm 0,2$ & $4,6 \pm 0,9$ & $4,7 \pm 0,2^{*, * * *}$ \\
\hline $\lg G, g / l$ & $8,0-1,66$ & $6,8 \pm 1,1$ & $11,1 \pm 1,3^{*}$ & $12,6 \pm 1,5^{*, * \star *}$ \\
\hline $\lg M, g / l$ & $0,5-1,3$ & $1,4 \pm 0,6$ & $1,6 \pm 0,4$ & $1,5 \pm 0,3$ \\
\hline $\mathrm{CIC}$, units. & $0-100$ & $81,5 \pm 5,2$ & $78,7 \pm 5,3$ & $32,4 \pm 3,2^{*, * \star *}$ \\
\hline Phl, \% & $40-80$ & $26,8 \pm 2,3^{* *}$ & $42,7 \pm 2,8^{*}$ & $77,2 \pm 4,5^{*, * * *}$ \\
\hline
\end{tabular}

Notes: * significance of differences compared with the source data $(\mathrm{p}<0.05)$; $*$ significance of differences compared with normal values $(p<0.05) ; * * *$ significance of differences compared with indicators of group $1(p<0.05)$

Dynamics of pro-inflammatory cytokines in patients of the Main Group (M $\pm \mathbf{m})$

\begin{tabular}{|c|c|c|c|c|c|c|c|c|}
\hline \multirow{2}{*}{$\begin{array}{c}\text { Interleukins, } \\
\mathrm{pg} / \mathrm{ml}\end{array}$} & \multirow{2}{*}{ Norm } & \multicolumn{7}{|c|}{ Day of observation } \\
\hline & & 1 Day & 3 Day & 5 Day & 7 Day & 10 Day & 14 Day & 25 Day \\
\hline IL-2 & $130,5 \pm 21,1$ & $72,2 \pm 5,3^{* *}$ & $136,3 \pm 5,2^{*, * * *}$ & $148,7 \pm 4,4^{*, * * *}$ & $168,1 \pm 3,1^{*, * *, * * *}$ & $156,3 \pm 6,4^{*, * * *}$ & $146,2 \pm 4,3^{*, * * *}$ & $129,3 \pm 2,2^{*, * * *}$ \\
\hline IL-6 & $303,1 \pm 10,4$ & $658,4 \pm 8,7^{* *}$ & $365,1 \pm 5,2^{*, * * * * * *}$ & $289,5 \pm 4,2^{*, * * *}$ & $346,4 \pm 6,3^{*, * * *}$ & $345,2 \pm 7,2^{* * * *}$ & $312,4 \pm 6,9^{*, * * *}$ & $301,1 \pm 8,2^{*, * * *}$ \\
\hline TNF- $\alpha$ & $4,27 \pm 1,23$ & $18,3 \pm 1,2^{* *}$ & $11,6 \pm 1,8^{* * * * *}$ & $6,8 \pm 1,5^{* * * *}$ & $11,3 \pm 1,1^{* * * * * * *}$ & $9,2 \pm 2,1^{* *, * * *}$ & $8,7 \pm 2,8^{*, * *, * * *}$ & $6,4 \pm 2,4^{* * * *}$ \\
\hline
\end{tabular}

Notes: * significance of differences compared with the source data $(\mathrm{p}<0.05)$; ** significance of differences compared with normal values $(\mathrm{p}<0.05)$; *** significance of differences compared with indicators of group $1(\mathrm{p}<0.05)$

ent from baseline. A more significant decrease was observed relative to the initial figures of the level of the CIC (32.4 \pm 3.2 units), while in the group of patients receiving conventional therapy, a significant increase occurred.

In addition, in patients of the Main Group, against the background of ongoing immunocorrective therapy, already on the $3^{\text {rd }}$ day of observation, the IL-2 concentration reached normal values $((136.3 \pm 5.2) \mathrm{pg} / \mathrm{ml})$. The upward trend continued for 7 days of observation, it was during these periods that the maximum concentration of IL-2 was recorded $((168.1 \pm 3.1) \mathrm{pg} / \mathrm{ml})$. Then there was a moderate decrease in the indicator and until the end of the observation, the values of the indicated cytokine were within normal limits (Table 4).

In the Comparison Group, normal IL-2 levels were recorded only on the 5th day, and by the end of the observation they decreased to critically low numbers. This fact confirms the feasibility of the early use of immunocorrective therapy for the treatment of patients with advanced peritonitis (Table 2).

The application of the proposed immunocorrection scheme allowed reducing the IL-6 concentration by 1.8 times on the third day, and on the 5th day this indicator reached normal values $((289.5 \pm 4.2) \mathrm{pg} / \mathrm{ml})$. Then, after a moderate increase in the concentration of the studied cytokine on the 7 th day $((346.4 \pm 6.3) \mathrm{pg} / \mathrm{ml})$, the level of IL6 fluctuated within the normal range until the end of the observation, in contrast to patients in the comparison group in which the level of IL-6 was elevated throughout the observation period (table. 4).
Before treatment, the concentration of TNF- $\alpha$ in patients of the study group, as in the comparison group, was several times higher than normal values. Starting from the third day, the TNF- $\alpha$ level in the patients of the study group was significantly lower than in the comparison group, and on the 5th day it reached the upper limit of the norm $(6.8 \pm 1.5 \mathrm{pg} /$ $\mathrm{ml})$. On the 7th day, the concentration of TNF- $\alpha$ increased again, after which there was a tendency to normalize the indicator. In the comparison group, the level of TNF- $\alpha$ increased during these periods (Table 4).

A dynamic study of the content of the cryocomplex in the studied patients established a decrease in the concentration of IgG and IgM, which, according to the immunological concept of the pathogenesis of peritonitis, is associated with the fixation of cryoglobulins in the mycirculatory bed with manifestations of autoimmune aggression against the intestinal epithelium. On the 7th day of the disease, an increase in the content of IgG cryocomplexes by $4.3 \%$ and a significant $(\mathrm{p} \leq 0.05)$ increase in $\operatorname{IgM}$ by $19.4 \%$ relative to the initial level were found. An increase in antibody content on the 7th day may be associated with the development of a secondary immune response. In some cases, an increase in the concentration of $\operatorname{IgG}$ and $\operatorname{IgM}$ with respect to their initial level occurred already on the third or fifth day of observation (Fig. 1).

Dynamic monitoring of cryoglobulinemia throughout the postoperative period in patients with peritonitis revealed the inadequacy of changes in their serum concentration depending on the time 
of observation (Fig. 1). In both groups of patients a decrease in the concentration of cryoglobulins was found on the 2nd day after surgery and a significant increase on the 3rd day. On the 5th day there was a decrease in the concentration of cryoproteins in the blood of patients from $(158.3 \pm 28.6) \mathrm{mcg} / \mathrm{ml}$ to (124.8 \pm 10.8$) \mathrm{mcg} / \mathrm{ml}$ in the Comparison Group and from $(132.4 \pm 82.2) \mathrm{mcg} / \mathrm{ml}$ to $(117,3 \pm 63.9) \mathrm{mcg} / \mathrm{ml}$ in the Main Group.

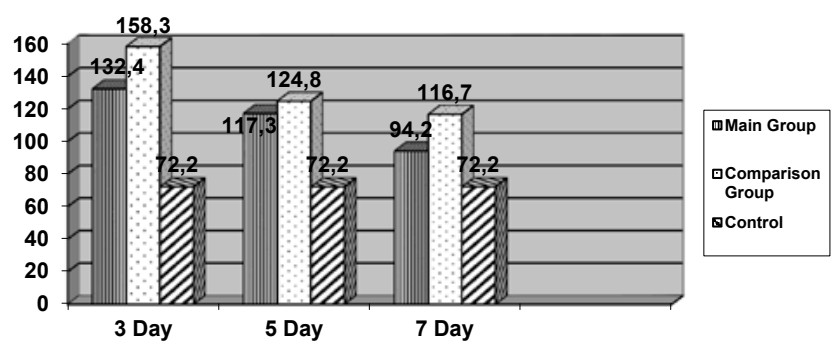

Fig. 1 Dynamics of the content of immunoglobulins in cryoprecipitate in patients with peritonitis

A dynamic study showed that before treatment, the content of nitric oxide in patients of the Main Group was $(38.4 \pm 1.6) \mathrm{mcmol} / \mathrm{ml}$ and did not significantly differ from the parameters of the comparison group (Fig. 2). On the third day, a significant decrease in the indicator to $(29.6 \pm 1.2) \mathrm{mcmol} / \mathrm{ml}$ was observed in patients of the Main Group, in contrast to patients of the Comparative Group, in which a significant increase in nitric oxide level was observed during this period. The peak concentration of the studied parameter in patients of the studied group was recorded on the 7th day $(41.4 \pm 2.2) \mathrm{mcmol} / \mathrm{ml})$, after which it decreased to the lower limit of the norm.

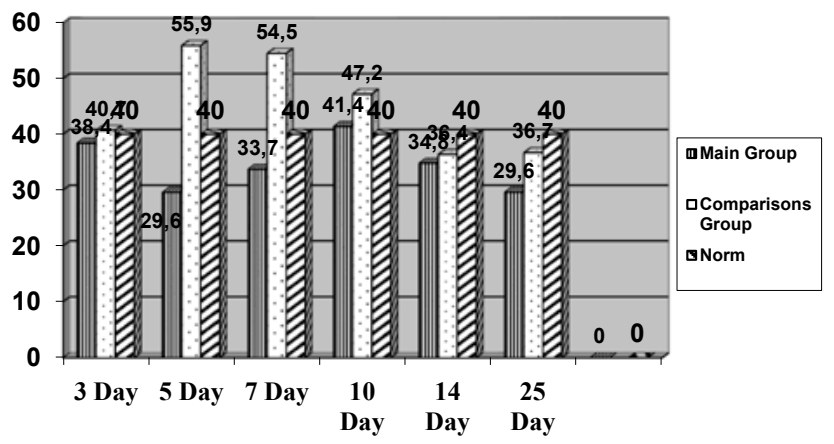

Fig. 2. Dynamics of the level of nitric oxide in patients with peritonitis

Noteworthy is the significant difference in the level of nitric oxide in the first day of the postoperative period, recorded between patients of the comparison group and the study group. It is known that an excessive increase in the concentration of nitric oxide in the first 2-3 days of the disease increases the risk of developing severe systemic and local complications. In patients of the main group there was no critical increase in the concentration of NO on the third day of observation. It is possible that stabilization of NO concentration in the early stages of observation helps to reduce the induction of the synthesis of pro-inflammatory cytokines, thereby preventing an excessive release of anti-inflammatory cytokines and, consequently, the development of depletion and decompensation of the body's immune system. Activation of the nitroxidergic system on the 7th day is the result of the directed action of pro-inflammatory cytokines to provide adequate antimicrobial protection. A decrease in the NO concentration during these periods in patients of the comparison group indicates a decrease in the body's ability to withstand microbial aggression. It should be noted that the maximum levels of NO and TNF- $\alpha$ were observed at the same time, which is probably due to the stimulating effect of immunomodulating therapy on antimicrobial defense mechanisms and the cellular immunity in response to a microbial attack.

A positive effect of immunocorrective therapy was also recorded in the study of the dynamics of apoptosis of peripheral blood ICC. During the first 5 days in the main group, a low percentage of ICC apoptosis was observed, on the 7th day there was a moderate increase (up to $8 \%$ ), after which the rate significantly decreased to $5 \%$, in the future, the level of apoptosis of ICC tended to decrease, and At the end of the observation, the minimum value of this indicator was recorded (Fig. 3).

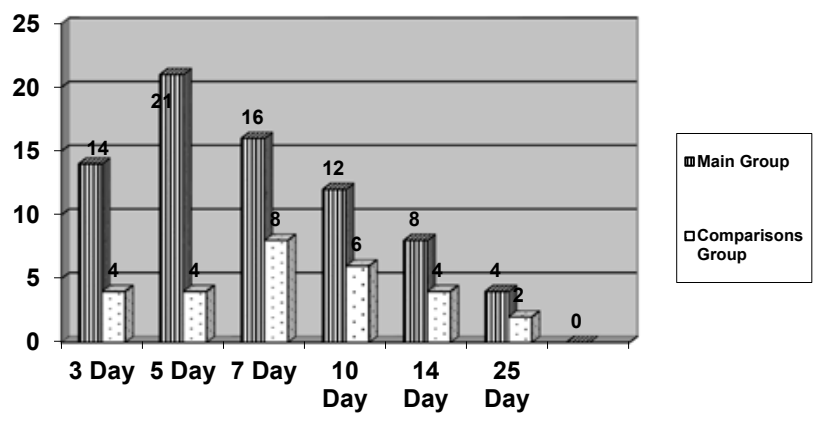

Fig. 3. Dynamics of immunocompetent cells apoptosis in patients with peritonitis

Thus, the results of the use of a comprehensive immunomodulation scheme using IL-2, galavit and $\alpha$-lipoic acid in the complex treatment of patients with widespread peritonitis against the background of intestinal anastomosis failure suggest that the developed scheme has a targeted immunoregulatory effect and prevents the excess production of inflammatory mediators in the early postoperative the period of the disease, helps to eliminate the cytokine imbalance and prevents the development of secondary immune deficiency.

The structure and nature of complications in groups are presented in table. 5 .

A comparative analysis of the incidence of complications revealed that in patients of the Main Group the average number of complications per pa- 
tient was 0.53 , while in the Comparison Group this indicator was 1.36 .

Table 5

Complications and mortality in patients of the studied groups

\begin{tabular}{|c|c|c|c|c|}
\hline \multirow{3}{*}{ Type of complication } & \multicolumn{4}{|c|}{ Groups } \\
\hline & \multicolumn{2}{|c|}{$\begin{array}{c}\text { Comparisons } \\
\text { Group, }(n=28)\end{array}$} & \multicolumn{2}{|c|}{$\begin{array}{l}\text { Main Group, } \\
(n=30)\end{array}$} \\
\hline & abs. & relat. & abs. & relat. \\
\hline Cardiovascular failure & 7 & 25 & 4 & 13.3 \\
\hline Respiratory failure & 4 & 14.3 & 3 & 10 \\
\hline Liver and kidney failure & 6 & 21.4 & 2 & 6.6 \\
\hline Sepsis & 3 & 10.7 & 1 & 3.3 \\
\hline Pneumonia & 3 & 10.7 & 1 & 3.3 \\
\hline $\begin{array}{l}\text { Perforation of acute bowel } \\
\text { ulcers }\end{array}$ & 2 & 7.1 & - & - \\
\hline $\begin{array}{l}\text { Intestinal anastomoses } \\
\text { leakege }\end{array}$ & 4 & 14.3 & 2 & 6.6 \\
\hline Interstitial abscess & 4 & 14.3 & - & - \\
\hline $\begin{array}{l}\text { Suppuration of a postop- } \\
\text { erative wound }\end{array}$ & 5 & 17.9 & 3 & 10 \\
\hline $\begin{array}{l}\text { The average number of } \\
\text { complications per patient }\end{array}$ & 1,36 & - & 0,53 & - \\
\hline Mortality, nomber ( \%) & 9 & 32.1 & 5 & 16.7 \\
\hline
\end{tabular}

Summing up, the accelerated stage I decreased from $17.9 \%$ in the group of the same age to $10 \%$ in the main group; Stage II - from 10.7 to $3.3 \%$, Stage IIIb - from 21.4 to $6.6 \%$ and Stage IV - from 39.3 to $23.3 \%$, Stage IVb - from 10.7 to $3.3 \%$ of that $\mathrm{V}$ level (mortality) - from 32.1 to $16.7 \%$ of all groups.

It should be noted that relaparotomy in patients of the Comparison Group regarding perforations of acute ulcers of the small intestine was performed in 2 cases $(7.1 \%)$, in the Main Group such cases were not registered. Insolvency of the intestinal complication occurred in $4(14.3 \%)$ patients in the Comparative Group and in $2(6.6 \%)$ cases in the Main Group. The causes of fatal cases in patients of the Main Group were pulmonary embolism ( 2 cases) and in three patients - acute cardiovascular failure. In the Cmparison Group, in most (7) cases, the progression of death was due to the progression of EI against the background of the MOF.

\section{Conclusions}

The use of a combination of IL-2, galavit and $\alpha$-lipoic acid in the complex of treatment of common peritonitis helps to reduce the level of systemic and local postoperative complications, as well as the level of postoperative mortality.

Immunocorrection should start from the first day a patient enters a hospital, and dosage adjustment of drugs must be carried out based on the revealed dynamics of the level of pro-inflammatory cytokines in this category of patients.

The use of the proposed treatment regimen for peritonitis has a stabilizing effect on the level of cytokines and nitric oxide and helps to reduce the severity of the systemic inflammatory reaction in the early postoperative period, helps to prevent the development of insufficiency of both non-specific and specific mechanisms of the immune system, and reduces the incidence of systemic and purulent complications of peritonitis, reduces mortality rates.

\section{LITERATURE}

1. Fomin PD, Matviychuk OB. (2018). Tertiary peritonitis as a problem of abdominal surgery. Klinicheskaia Khirurgiia. 2018;1:49-51. https://doi.org/10.26779/25221396.2018.01.49

2. Kryvoruchko IA, Boyko VV, Ivanova YV, Andreieshchev SA. Sepsis-3: renewed determinations, potential problems and further practical foot steps. Klinicheskaia Khirurgiia. 2019;86(6):60-72. https://doi.org/10.26779/25221396.2019.06.60

3. Berlot G, Tomasini A, Viviani M. SIRS, Sepsis, and MODS. Infection Control in the Intensive Care Unit:537-47. https://doi.org/10.1007/88-470-0361-X_24

4. Orlov Y.I. Intravascular Hemolysis of Red Blood Cells in the Development of Organ Dysfunctions in Critical Conditions. General Reanimatology. 2008;4(2):88. (In Russ.) https://doi.org/10.15360/1813-9779-2008-2-88

5. Kim PK, Deutschman CS. Inflammatory responses and mediators. Surgical clinics. 2000;Vol.80;Iss.3:885-94. https://doi.org/10.1016/S0039-6109(05)70102-X

6. Karandin VI, Rozhkov AG, Tsarev MI, Nagayev RM, Tikhonov PA. Evaluation of the Severity of Surgical Endotoxicosis. General Reanimatology. 2009;5(5):49. (In Russ.) https://doi.org/10.15360/1813-9779-2009-5-49

7. Skripko VD, Kovalenko AL, Zaplutanov VA. Korrekcija narushenij mikrojelementnogo gomeostaza i okislitelnogo stressa u pacientov s ostroj tonkokishechnoj neprohodi- mostiu. Hirurgija. Zhurnal im. N.I. Pirogova. 2017;6: 55-59. https://doi.org/10.17116/hirurgia2017655-59

8. Green J, Doughty L, Kaplan SS, Sasser H, Carcillo JA. The Tissue Factor and Plasminogen Activator Inhibitor Type-1 Response in Pediatric Sepsis-induced Multiple Organ Failure. Thromb Haemost. 2002;87(02): 218-23. https://doi.org/10.1055/s-0037-1612976

9. Sartelli M, Abu-Zidan FM, Labricciosa FM, et al. Physiological parameters for Prognosis in Abdominal Sepsis (PIPAS) Study: a WSES observational study. World J Emerg Surg. 2019;14:34. https://doi.org/10.1186/s13017019-0253-2

10. Glukhov AI, Gryzunova GK, Usai LI, Aleynikova TL, Chernikova NV, Burt AY. The Role of Apoptosis in the Pathogenic Mechanism of Critical States (Review). General Reanimatology. 2019;15(2):79-98. (In Russ.) https:// doi.org/10.15360/1813-9779-2019-2-79-98

11. Aird WC. The role of the endothelium in severe sepsis and multiple organ dysfunction syndrome. Blood;2003;101(10):3765-77. https://doi.org/10.1182/ blood-2002-06-1887

12. Osuchowski MF, Welch K, Siddiqui J, Remick DG. Circulating Cytokine/Inhibitor Profiles Reshape the Understanding of the SIRS/CARS Continuum in Sepsis and Predict Mortality. J Immunol. 2006;177:1967-74. doi: 10.4049/jimmunol.177.3.1967 
ПРОФІЛАКТИКА РАННІХ

ПІСЛЯОПЕРАЦИЙНИХ

УСКЛАДНЕНЬ ОПЕРАЦИЙ

НА КИШЕЧНИКУ 3

ВИКОРИСТАННЯМ

ІМУНОМОДУЛЮЮЧОї

ТЕРАПІї

\section{М.}

Резюме. Метою дослідження є розробка методу імунокорекції, який покращує результати лікування пацієнтів з розвиненим перитонітом на тлі протікання анастомозу тонкої кишки шляхом зупинки каскаду ССЗВ та ПОН.

Матеріали та методи. Робота була клінічного характеру, виконувалася в клініці СІ «ЗІГУС НАМСУ» в період 32016 по 2019 рік. Ми обстежили 58 пацієнтів з різними захворюваннями органів черевної порожнини, ускладненими перитонітом, резекцією сегменту тонкої кишки. Група порівняння включала пацієнтів, які отримували традиційну терапію, в лікуванні пацієнтів основної групи комплекс медикаментозної терапії включав рекомбінантний інтерлейкін-2, галавіт та $\alpha$-ліпоєву кислоту. Результати хірургічного лікування оцінювали згідно 3 класифікацією D. Dindo, N. Demartinesta P.-A. Clavien (2004). Статистичний аналіз виконувався на програмному забезпеченні Statistica 6.0 (StatSoft, Inc. 2001) та SPSS 7.5 на ПК Apple.

Результати та обговорення. Результати використання комплексної схеми імуномодуляції із застосуванням ІЛ-2, галавіту та $\alpha$-ліпоєвої кислоти при комплексному лікуванні хворих на поширений перитоніт на тлі недостатності кишкового анастомозу свідчать про те, що схема має цілеспрямований імунорегуляторний ефект і запобігає надлишковій продукції медіаторів запалення в ранньому післяопераційному періоді захворювання, допомагає усунути цитокіновий дисбаланс і запобігає розвитку вторинного імунодефіциту. Порівняльний аналіз частоти ускладнень показав, що серед пацієнтів основної групи середня кількість ускладнень на одного пацієнта становила 0,53 , тоді як у групі порівняння цей показник становив 1,36.

Висновки. Використання комбінації ІЛ-2, галавіту та $\alpha$-ліпоєвої кислоти в комплексі лікування поширеного перитоніту допомагає знизити рівень системних та локальних післяопераційних ускладнень, а також рівень післяопераційної летальності.

Ключові слова: неспроможність анастомозу, перитоніт, імуномодулююча терапія. 
ПРОФИЛАКТИКА РАННИХ ПОСЛЕОПЕРАЦИОННЫХ ОСЛОЖНЕНИЙ ОПЕРАЦИЙ НА КИШЕЧНИКЕ С ИСПОЛЬЗОВАНИЕМ ИММУНОМОДУЛИРУЮЩЕЙ ТЕРАПИИ

\section{М. Е. Тимченко}

Резюме. Целью исследования является разработка метода иммунокоррекции, который улучшает результаты лечения пациентов с развитым перитонитом на фоне протекания анастомоза тонкой кишки путем остановки каскада ССВО и ПОН. Материалы и методы. Работа была клинического характера, выполнялась в клинике ГУ «ИОНХ им. В.Т.Зайцева НАМНУ» в период с 2016 по 2019 год. Мы обследовали 58 пациентов с различными заболеваниями органов брюшной полости, осложненными перитонитом, с резекцией участков тонкой кишки. Группа сравнения включала пациентов, получавших традиционную терапию, в лечении пациентов основной группы комплекс медикаментозной терапии включал рекомбинантный интерлейкин-2, галавит и $\alpha$-липоевую кислоту. Результаты хирургического лечения оценивали по классификации D. Dindo, N. Demartinesta P.-A. Clavien (2004). Статистический анализ производился с использованием программного обеспечения Statistica 6.0 (StatSoft, Inc. 2001) и SPSS 7.5 на ПК Apple.

Результаты и обсуждение. Результаты использования комплексной схемы имуномодуляции с применением ИЛ-2, Галавита и $\alpha$-липоевой кислоты при комплексном лечении больных распространенный перитонит на фоне недостаточности кишечного анастомоза свидетельствуют о том, что предложенная схема имеет целенаправленный иммунорегуляторный эффект и предотвращает избыточной продукции медиаторов воспаления в раннем послеоперационном периоде заболевания, помогает устранить цитокиновый дисбаланс и предотвращает развитие вторичного иммунодефицита. Сравнительный анализ частоты осложнений показал, что среди пациентов основной группы среднее число осложнений на одного пациента составляла 0,53 , тогда как в группе сравнения этот показатель составлял 1,36.

Bыводы. Использование комбинации ИЛ-2, Галавита и $\alpha$-липоевой кислоты в комплексе лечения распространенного перитонита помогает снизить уровень системных и локальных послеоперационных осложнений, а также уровень послеоперационной смертности.

Ключевые слова: несостоятельность анастомоза, перитонит, иммуномодулирующая терапия. 